Bedankt voor het downloaden van dit artikel. De artikelen uit de (online)tijdschriften van Uitgeverij Boom zijn auteursrechtelijk beschermd. U kunt er natuurlijk uit citeren (voorzien van een bronvermelding) maar voor reproductie in welke vorm dan ook moet toestemming aan de uitgever worden gevraagd.

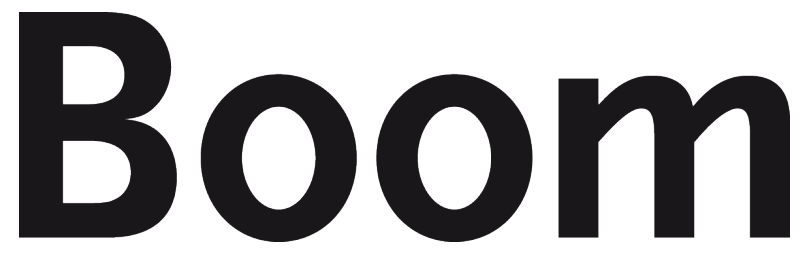

Behoudens de in of krachtens de Auteurswet van 1912 gestelde uitzonderingen mag niets uit deze uitgave worden verveelvoudigd, opgeslagen in een geautomatiseerd gegevensbestand, of openbaar gemaakt, in enige vorm of op enige wijze, hetzij elektronisch, mechanisch door fotokopieën, opnamen of enig andere manier, zonder voorafgaande schriftelijke toestemming van de uitgever.

Voor zover het maken van kopieën uit deze uitgave is toegestaan op grond van artikelen $16 \mathrm{~h} \mathrm{t} / \mathrm{m} \mathrm{16m}$ Auteurswet 1912 jo. Besluit van 27 november 2002, Stb 575, dient men de daarvoor wettelijk verschuldigde vergoeding te voldoen aan de Stichting Reprorecht te Hoofddorp (postbus 3060, 2130 KB, www.reprorecht.nl) of contact op te nemen met de uitgever voor het treffen van een rechtstreekse regeling in de zin van art. 16l, vijfde lid, Auteurswet 1912.

Voor het overnemen van gedeelte(n) uit deze uitgave in bloemlezingen, readers en andere compilatiewerken (artikel 16, Auteurswet 1912) kan men zich wenden tot de Stichting PRO (Stichting Publicatie- en Reproductierechten, postbus 3060, 2130 KB Hoofddorp, www.cedar.nl/pro).

No part of this book may be reproduced in any way whatsoever without the written permission of the publisher.

info@boomamsterdam.nl www.boomuitgeversamsterdam.nl 


\title{
REDACTIONEEL
}

\section{Wetenschap, beleid en media}

\author{
Patricia van Echtelt \& Roel Schouteten*
}

Een van de Founding Fathers van het Tijdschrift voor Arbeidsvraagstukken, Jacques van Hoof, beschreef in het allereerste nummer helder waarom de oprichting van dit tijdschrift toen van belang was (Van Hoof, 1985). ${ }^{1}$ Hij noemt het opmerkelijk dat maar zo weinig van de resultaten van onderzoek doordringt tot een breder publiek dan de onderzoekerswereld. De ontoegankelijkheid - mede als gevolg van het gebezigde taalgebruik - en de opdeling van het onderzoeksterrein in verschillende op zichzelf staande deelgebieden lagen daar volgens hem aan ten grondslag. De oprichters stelden zich tot doel meer bekendheid te geven aan sociaalwetenschappelijk onderzoek op het terrein van arbeid; niet alleen bij wetenschappers, maar ook bij een breder in onderzoek geïnteresseerd publiek. Hoewel gerichtheid op actualiteit en beleid centraal stond, was het niet zozeer het doel allerlei ontwikkelingen op de voet te volgen, maar om actuele problemen vanuit een wetenschappelijke benadering te analyseren en deze in een breder verband te plaatsen.

Ruim dertig jaar later is er veel veranderd in de wetenschap en de wereld van de media. Heeft deze doelstelling daarmee inmiddels niet haar houdbaarheid verloren? We denken van niet en beweren zelfs dat deze taak belangrijker - of urgenter - is dan ooit. Daar zijn verschillende redenen voor, we noemen er een aantal.

Om te beginnen heeft de input van onafhankelijk onderzoek bij de aanpak van arbeidsvraagstukken niet aan belang ingeboet. Wetenschappelijk onderzoek draagt eraan bij dat aannames die aan beleid ten grondslag liggen, realistisch zijn en dat de veronderstelde effecten niet politiek en beleidsmatig zijn gekleurd. Dat geldt voor overheidsbeleid, maar net zo goed voor maatregelen van bijvoorbeeld werkgevers in het personeelsbeleid van hun organisatie of voor de re-integratiepraktijk in het socialezekerheidsdomein. Dit rationalistische beeld van wetenschap en samenleving is de afgelopen decennia waarschijnlijk niet wezenlijk veranderd. Een wetenschappelijke grondslag voor beleid wordt wenselijk geacht, al moet de rol van wetenschappelijke kennis bij het falen of slagen van beleidsmaatregelen ook niet worden overschat (Schuyt, 2006).

Vanuit dit uitgangspunt valt op dat de door Van Hoof genoemde ontoegankelijkheid van wetenschappelijk onderzoek - mede door het gebezigde taalgebruik in de afgelopen dertig jaar er een nieuwe dimensie bij heeft gekregen. Wetenschappers aan universiteiten publiceren in toenemende mate alleen in internati-

* Patricia van Echtelt is lid van de redactie van TvA en is verbonden aan het Sociaal en Cultureel Planbureau. E-mail: P.van.Echtelt@scp.nl. Roel Schouteten is lid van de redactie van TvA en is verbonden aan het Institute for Management Research van de Radboud Universiteit. 
onale Engelstalige tijdschriften. Aan de universiteiten is een rat race gaande waarbij vrijwel alleen publicaties in internationale tijdschriften gelden als succes. Kennisdisseminatie en 'valorisatie' voor de Nederlandse samenleving staan weliswaar expliciet op de universitaire agenda, maar onderzoekers worden toch vooral gestuurd op internationale output. Het brede in onderzoek geïnteresseerde publiek heeft nauwelijks toegang tot deze publicaties, en ook het 'gebezigde taalgebruik' is er met de internationalisering niet toegankelijker op geworden. Vanuit dit perspectief lijkt de kloof tussen de wereld van de wetenschap en van het beleid eerder groter dan kleiner te worden. Het blijft dus belangrijk om bruggen te slaan tussen wetenschap en beleid en de dialoog aan te gaan (zie ook het essay van Kim Putters in dit nummer). We denken dat de Nederlandstalige wetenschappelijke tijdschriften hierbij een belangrijke rol hebben te vervullen.

Een andere ontwikkeling die zich de afgelopen decennia in hoog tempo heeft voltrokken, is het gebruik van sociale media voor kennisverspreiding. Met deze snelle manier van communiceren is het steeds beter mogelijk actualiteiten op de voet te volgen. Het is ook een manier om onderzoeksrapporten en wetenschappelijke artikelen onder de aandacht te brengen van een groot publiek. Het moet echter wel duidelijk blijven waar de kennis op gebaseerd is en dat deze niet los komt te staan van een bredere context. Wetenschappelijke kennis is immers niet gebaseerd op meningen. Het geeft geen snelle antwoorden op beleidsvragen (meningen over wat er moet gebeuren), maar op kennisvragen (Derksen, 2011). Kennisdisseminatie via sociale media is dus een groot goed, maar het ontslaat de wetenschapper niet van gedegen onderzoek. Noch van de verantwoordelijkheid openlijk te publiceren over hoe de resultaten en conclusies tot stand zijn gekomen. Nederlandstalige wetenschappelijke tijdschriften blijven dus ook op dit punt onverminderd noodzakelijk en actueel.

\section{Primeurs}

Verandert er dan nooit iets aan het Tijdschrift voor Arbeidsvraagstukken? Jazeker wel. In de afgelopen nummers deed het essay al zijn intrede als nieuwe rubriek. In dit eerste nummer van 2018 introduceren we twee primeurs, die in lijn liggen met de genoemde doelstellingen en ontwikkelingen.

Op de eerste plaats presenteren we in deze editie voor het eerst in de geschiedenis van TvA een 'lente-artikel' ${ }^{\text {' }}$ van de secretaris-generaal van het ministerie van Sociale Zaken en Werkgelegenheid (SZW), Loes Mulder. Zij neemt een belangrijk actueel beleidsvraagstuk onder de loep, namelijk het langer doorwerken van oudere werknemers. Wij vinden het belangrijk de dialoog tussen beleidsmakers en wetenschap te faciliteren en zijn dan ook bijzonder verheugd om in dit nummer de eerste editie van het voorjaarsartikel van SZW te kunnen etaleren. Op de tweede plaats introduceren we de rubriek 'Gepubliceerd internationaal'. Hierin presenteren wetenschappers aan Nederlandse en Vlaamse universiteiten op een toegankelijke manier de resultaten van onderzoek dat zij recent in internationale tijdschriften hebben gepubliceerd. Hun onderzoek richt zich op arbeidsvraagstukken die actueel en beleidsrelevant zijn. Hiermee hopen we 
tegemoet te komen aan de behoefte om wetenschappelijk onderzoek voor het breder publiek toegankelijk te maken.

\section{Noten}

1 Dankzij recente digitalisering van het archief zijn de oudere jaargangen van TvA (1985-2004) nu ook digitaal te raadplegen (via https://ugp.rug.nl/arbeidsvraagstukken).

2 Naar goed voorbeeld van het nieuwjaarsartikel van de secretaris-generaal van het ministerie van Economische Zaken in Economisch Statische Berichten.

\section{Literatuur}

Derksen, W. (2011). Kennis en beleid verbinden: Praktijkboek voor beleidsmakers. Den Haag: Boom Lemma.

Schuyt, K. (2006). Kameleontisch beleid, stekelige wetenschap. In K. Schuyt, J.W. Duyvendak, T. Roes (red.), Werken op de grens van wetenschap en beleid (pp. 11-25). Den Haag: Sociaal en Cultureel Planbureau.

Van Hoof, J.J. (1985). Een Nederland-Belgisch forum over arbeidsvraagstukken. Tijdschrift voor Arbeidsvraagstukken, 1(1), 2-3. 